\title{
Pastors as gewonde genesers: \\ Die emosionele uitwerking van kognitiewe dissonansie
}

\author{
S Philip Nolte \& Yolanda Dreyer ${ }^{1}$ \\ Departement Praktiese Teologie \\ Universiteit van Pretoria
}

\begin{abstract}
Pastors as wounded healers: Emotional experience and cognitive dissonance

The relevance of reflecting on pastors' identity and ministry is precipitated by the paradigm shift from modernity to postmodernity. Pastors often suffer from cognitive dissonance because of the paradigm shift. This dissonance comes to the fore in that pastors and the people they are supposed to serve, frequently find themselves in different, opposing worlds. In their attempt to adapt to this situation, pastors often experience emotional woundedness and do not always have the psychological disposition and skills to process their emotions in intelligent and creative ways. The paradigm shift in the Christian faith community can be described as a movement from a traditional to an emerging paradigm. This article aims to reflect on the meaning of this movement for pastors and their functioning in a new world.
\end{abstract}

\section{INLEIDING}

In 2005 verskyn 'n betekenisvolle bundel opstelle oor beelde/metafore in pastorale sorg aan die hand waarvan praktiese teoloë, wat hulle op die gebied van pastoraat en pastorale sorg toespits, oor pastors en pastorale identiteit reflekteer. Hierdie bundel staan onder die redakteurskap van Robert C Dykstra, medeprofessor in pastorale teologie aan die toonaangewende Princeton Theological Seminary en verskyn onder die titel Images of pastoral

\footnotetext{
${ }^{1}$ Hierdie artikel is 'n verwerking van 'n gedeelte van hoofstuk 1 van S Philip Nolte (2008) se PhD proefskrif getiteld, Pastors as gewonde genesers: Emosionele intelligensie en pastoraat, onder leiding van prof dr Yolanda Dreyer, Departement Praktiese Teologie, Fakulteit Teologie, Universiteit van Pretoria.
} 


\section{Pastors as gewonde genesers}

care: Classic readings. Dykstra dra die boek op aan sy vriend en kollega, Donald Capps, nog 'n invloedryke praktiese teoloog van Princeton. Die boek bestaan uit bydraes deur verskillende praktiese (pastorale) teoloë van wie sommige reeds oorlede is, maar as pioniers op die gebied van pastoraat geag word. Van hierdie teoloë is onder andere Anton T Boisen, Charles V Gerkin, Annie Miller-McLemore, Seward Hiltner, Henri J M Nouwen, Heije Faber, Donald Capps, James E Dittes en Brita L Gill-Austern.

Dykstra (2005:1-4) wys op die "ironiese" relasie tussen die ontstaan van die kliniese pastorale opleiding van pastors in die VSA en die psigiese ineenstorting van Anton T Boisen in die jare twintig van die vorige eeu. $\mathrm{Na}$ aanleiding van sy ervarings in ' $n$ instituut vir geestelik vesteurde mense het Boisen hom na sy herstel daarop ingestel om sy eie ervarings te probeer verstaan en veral oor die religieuse dimensie van sy eie en sy mede pasiënte se ervarings na te dink (kyk Boisen 2005:22-29). Dykstra (2005:3-4) wys verder op die voortdurende selfrefleksie waaraan pastorale teoloë en pastors hulleself en hulle vakgebied onderwerp en vra aan die hand van 'n Britse psigoanalis, Nina Coltart, se kritiese refleksie oor haar eie beroep (Dykstra 2005:3) die vraag waarom hierdie selfkritiese ingesteldheid van die begin af deel van die pastorale teologie was? Dykstra (2005:3) formuleer sy antwoord daarop soos volg: "... psychoanalysts seek to know the unconscious, that part of the self or soul that, by definition, is unknowable. How much more so the case, then, the madness of ministers in their attempts to know and speak on behalf of an unknowable, unspeakable God?" Hierdie antwoord verklaar die rede waarom Dykstra se boek 'n versameling van verskillende metafore is aan die hand waarvan daar oor pastors en pastorale identiteit besin word.

Metaforiese spreke is 'n erkenning daarvan dat daar slegs voorlopig oor 'n bepaalde saak gepraat kan word, omdat dieselfde saak ook vanuit die gesigspunte van ander metafore beskryf kan word. Die feit dat 'n wye reeks metafore aangebied word, kommunikeer die oortuiging dat daar nie op eendimensionele wyse oor pastoraat besin kan word nie. Die multidissiplinêre benadering wat in die verskillende hoofstukke aan die lig kom, bevestig dat pastorale teoloë poog om verantwoordelik met insigte vanuit onder andere die psigologie, sosiale wetenskappe, Bybelwetenskappe en literatuurwetenskap om te gaan en in hulle besinning te integreer. Daar is een deurlopende tema wat in al die bydraes na vore kom en dit is dat daar gepoog word om insigte vanuit die ander dissiplines teologies te integreer. Verskillende pastorale teoloë se refleksie oor metafore soos "the living human document" (Anton T Boisen), "the living human web" (Bonnie J Miller-McLemore), "the selfdifferentiated Samaritan" (Jeanne Stevenson Moessner), "the wounded healer" (Henri J M Nouwen), "the intimate stranger" (Robert C Dykstra), "the 
agent of hope" (Donald Capps), "the midwife" (Karen R Hanson)" en "the gardener" (Margaret Zipse Kornfeld) is in die bundel opgeneem. Die rede vir hierdie wye reeks metafore is om pastors asook voorgraadse en nagraadse teologiese studente van 'n sinvolle, kompakte inleiding op die gebied van die pastorale teologie te verskaf en hulle tegelyk aan die problematiek, maar ook aan kreatiewe besinning, binne pastoraal-teologiese kringe bekend te stel (Dykstra 2005:10-12).

Die feit dat Nouwen se besinning oor die wounded healer in hierdie resente werk opgeneem is, bevestig my oortuiging dat daar 'n behoefte bestaan vir wat genoem kan word "n pastoraat vir pastors". Hierdie behoefte word ook geïllustreer deur 'n werksdokument wat tydens 'n eerste werksessie op 12 Junie 2007 aan dosente van die Fakulteit Teologie aan die Universiteit van Pretoria aangebied is, met betrekking tot die universitêre opleiding van pastors. Die titel van die werksdokument is Profiel van die afgestudeerde predikant met die oog op bediening in die Nederduitse Gereformeerde Kerk en die Nederduitsch Hervormde Kerk. Onder die rubriek "Karakter- en persoonsontwikkeling" (2.9 van die dokument) word die volgende gesê: "Dit sluit onder meer in dat die student ... iemand is wat die gebrokenheid van die lewe verstaan, weet dat lyding deel is van die lewe en sy/haar eie gebrokenheid erken en bereid is om as 'gewonde geneser' te dien". Die doel van hierdie artikel is om teen hierdie agtergrond sekere kantaantekeninge te maak oor 'n "pastoraat vir pastors" deur spesifiek op die emosionele en spirituele dimensies van pastors se menswees te fokus.

Die vertrekpunt van die studie is dat pastors se erkenning van hulle eie verwonding voorwaarde vir meer effektiewe pastorale begeleiding van ander is. Hierdie oortuiging vind weerklank in Miller-McLemore (1996:21-22) se waarneming dat Boisen se psigiese en emosionele ineenstorting hom daartoe gebring het om die gemarginaliseerde en geostraseerde identiteit wat dikwels aan individue en groepe in instellings vir geestesversteurdheid gekoppel word, in duideliker perspektief te sien. Hierdie studie wil aantoon dat pastors wat vanweë bepaalde gebeure emosionele verwonding en trauma beleef, hulleself nie as gemarginaliseerd hoef te beleef nie, maar daardie verwonding juis as 'n beginpunt van emosionele en spirituele heling kan interpreteer.

\section{INNERLIKE VERWONDING}

Pastors sien hulleself as mense wat ander op 'n sinvolle wyse moet begelei, sodat daardie mense met integriteit as heel mense kan leef. Die mense wat pastors wil begelei, ervaar verwonding op verskillende vlakke. Die fasilitering van 'n proses om op 'n sinvolle wyse met hierdie verwonding om te gaan, verg insig, wysheid en emosionele energie van pastors. Omdat pastors mense is, 


\section{Pastors as gewonde genesers}

ervaar hulle self ook innerlike verwonding. Hierdie verwonding kan ook as integriteitsverlies beskryf word, waarmee bedoel word dat pastors vanweë hulle eie verwonding nie as heel mense leef nie. As gevolg van hulle eie verwonding beleef pastors verlamming wat manifesteer as 'n gebrek aan emosionele energie om hulle bediening sinvol uit te voer.

Die verlamming wat pastors beleef, bestaan daaruit dat hulle nie self duidelik weet wat die inhoud van hulle verwonding is nie. Soms bestaan daar 'n vae vermoede by pastors dat hulle verwonding spruit uit spanning met betrekking tot die relasie tussen hulle bediening - wat hulle teologiese besinning insluit - en hulle menswees. Gerben Heitink ([1977] 1984:16; beklemtoning bygevoeg) formuleer hierdie relasie soos volg: "Daarbij moet onderscheid gemaakt worden tussen zijn persoonlijke identiteit en zijn pastorale identiteit. Vooral twee vragen duiken in dit verband regelmatig op: Wie ben ik? Wat kom ik doen? Terecht ... dat er geen beroep is, waarbij persoonlijke existentie en ambt zozeer verweven zijn als bij een pastor het geval is." Heitink se insig vestig die aandag op die noue verband tussen pastors se innerlike lewe en die praktiese uitvoering van hulle bediening, wat impliseer dat pastors se emosies en emosionele verwonding in hulle bediening meespeel. Die doel van pastorale interaksie tussen pastors en ander is heling en heelheid - dat mense psigies en geestelik sal genees van hulle wonde en sal groei in menswees en geloof en in diensbaarheid.

Verwonding in pastors se lewens veroorsaak dat hulle trauma in terme van hulle selfbesef beleef, wat 'n pynlike en verwarrende ervaring kan wees en hulle menswees en bediening negatief beïnvloed. Hoewel emosionele verwonding negatief ervaar word en hierdie trauma dikwels nie op 'n sinvolle wyse deur mense verwerk word nie, kan verwondheid vir pastors op paradoksale wyse as bron tot genesing in hulle eie lewens asook in hulle interaksie met ander dien. Die moontlikheid dat pastors op grond van hulle eie emosionele verwonding as gewonde genesers kan funksioneer, is die motivering vir hierdie studie. In sy boek, The wounded storyteller: Body, illness, and ethics (1995), reflekteer Arthur W Frank oor die krag van siek mense se narratiewe en verwoord hierdie saak soos volg (Frank 1995:xii): "The ill, and all those who suffer, can also be healers. Their injuries become the source of the potency of their stories. Through their stories, the ill create empathic bonds between themselves and their listeners." Frank (1995:xii; beklemtoning bygevoeg) gaan dan voort en bring sy beskouing soos volg in relasie met die "wounded healer" metafoor van Nouwen: "Because stories can heal, the wounded healer and wounded storyteller are not separate, but are different aspects of the same figure." In 'n baie besondere sin is my studie 
deel van my eie lewensverhaal van verwonding. Die probleem en vraagstelling van hierdie artikel spruit voort uit wat as pastors se innerlike verwonding beskryf kan word.

\section{KOGNITIEWE DISSONANSIE}

Die vraag waarom pastors innerlike verwondheid of verlamming beleef, kan vanuit die wetenskapsteorie beantwoord word as dat dit te doen het met die gevolg van 'n verskuiwing van 'n moderne na 'n postmoderne paradigma. Postmoderniteit word onder andere deur relativering van baie van die sekerhede uit die moderne era gekenmerk. Dit hou in dat ook godsdienstige en Bybelse "sekerhede" in gedrang kom. Hierdie relativering lei tot onsekerheid en ambivalensie as gevolg van die "kompleksiteit en multidimensionaliteit van die vrae, probleme en uitdagings waarvoor die predikant te staan kom. Die ambivalensie word verder versterk deur die dinamiek van vele religieuse veranderings wat plaasgevind het op die makrovlak van die samelewing, die mesovlak van die kerk en die mikrovlak van die individu" (Malherbe \& Louw 2002:516).

Die verlamming wat pastors as gevolg van die verskuiwing van die moderne na die postmoderne paradigma beleef, kan as kognitiewe dissonansie omskryf word. Dit is 'n aangeleentheid wat verband hou met "kennis" wat nie in pas is met die realiteite in die lewe waarmee mense daagliks moet rekening hou nie. So byvoorbeeld kan 'n roker kennis hê van die mediese risiko's van rook, maar nie die realiteit van verslawing aan nikotien ontsnap nie. Kognitiewe dissonansie is wanneer gelowiges in die kerk hulle op sogenaamde "objektiewe kennis" van norme (in die Bybel en in die kerklike tradisie) beroep, maar die realiteite van die lewe bots met hierdie afgeleide rasionele norme. Hierdie verskynsel kan besonder kompleks van aard wees. Dit is omdat mense hulle in kommunikatiewe interaksie met ander mense binne dieselfde sosiale kontekste bevind. Hierdie interaksie word singewend wanneer die kennisname van mekaar gegrond word in 'n dinamiek wat mense laat saam voel of van mekaar wegstoot. M A K Holliday (1978) toon aan dat kennis van ander en van sigself drieërlei van aard is: wat/wie/waar/wanneer-kennis; hoe-kennis; waarvan-kennis (kyk ook Malina 2001:7-19). Tussenmenslike reaksies word gebou deur kommunikasie wat bepaal word deur kennis van hoe gevoel, gedink en gehandel moet word, op grond van kennis wat uit waarneming voortspruit. Kognitiewe dissonansie volg op gevoel, denke en handeling wat uit pas is met wat mense weet. Daarom struikel mense in interaksie omdat hulle nie weet hoe om te handel na 


\section{Pastors as gewonde genesers}

aanleiding van oordele op grond van kennis waarvan hulle hul evaluasie moet aflei nie.

Vir pastors bestaan hierdie dissonansie daaruit dat hulle en die mense met wie hulle in interaksie tree, hulleself binne dieselfde konteks (postmoderne kultuur), maar binne verskillende paradigmas, bevind. Pastors in die Reformatoriese tradisie staan binne 'n teologiese tradisie waarin die Bybel as belangrik geag word en derhalwe poog hulle om die Bybel in hulle bediening ter sprake te bring. Die Reformatories-teologiese tradisie, met die belangrike plek wat kerklike belydenisse en belydenisskrifte daarin inneem, bepaal ook die wyse waarop pastors die Bybel lees en in diskoerse betrek. In hierdie opsig bevind menige pastors hulleself binne 'n moderne paradigma, met die beskouing dat die Bybel en teologiese tradisie "afdoende antwoorde" op hedendaagse probleme verskaf. Die mense wat pastors bedien, leef egter binne 'n postmoderne kultuur wat op vele wyses die aanname dat die Bybel en belydenisskrifte as "norm" vir mense se verhouding met God en vir hulle geloof en lewens behoort te geld, problematiseer. Daar is ook lidmate wat hulleself op religieuse vlak alreeds binne die postmoderne paradigma bevind, maar hulle pastors en geloofsgemeenskap/-pe funksioneer nog vanuit die modernistiese paradigma.

Marcus Borg beskryf in sy boek The heart of Christianity: Rediscovering a life of faith (2003) die oorgang van moderniteit na postmoderniteit in die Christelike geloofstradisie aan die hand van sy onderskeid tussen 'n vroeëre (tradisionele) paradigma en 'n opkomende paradigma. David Tracy (1994:104-114) beskryf postmoderniteit as 'n transformasie van institusionele godsdiens, as uitvloeisel van moderniteit, na postmoderne spiritualiteite. Die oorgang van moderniteit na postmoderniteit kan ook as 'n kairos moment vir die Christelike teologie beskryf word (kyk Hodgson 1994).

'n Paradigma is "a large interpretive framework that shapes how everything is seen, a way of constellating particulars into a whole" (Borg 2003:4). Die verskuiwing van 'n geosentriese (Ptolemeïse) na 'n heliosentriese (Kopernikaanse) beskouing oor die heelal dien as voorbeeld van die wyse waarop 'n verandering die geheel van mense se denke beïnvloed (Borg 2003:5). So 'n verandering is meer as verskillende "perspektiewe" op dieselfde saak, of van kleiner dele van die geheel - 'n paradigmaverandering raak die geheel van mense se lewens en dien as raamwerk van waaruit hulle hulle bestaan en die werklikheid waarbinne hulle leef, interpreteer. Dieselfde data word waargeneem, maar word vanuit paradigmas wat geheel en al van mekaar verskil, verstaan en geïntegreer. 
Baie lidmate van die Christelike geloofstradisie bevind hulle binne die vroeë, tradisionele paradigma, terwyl baie ander hulleself binne die nuwe, opkomende paradigma bevind. Laasgenoemde groep vind toenemend moeite om binne geloofsgemeenskappe te bly waar die tradisionele paradigma nog geld, net soos wat mense in die eersgenoemde groep frustrasie ervaar binne geloofsgemeenskappe waar die nuwe, opkomende paradigma na vore begin kom (Borg 2003:2-4; kyk Webster 2003; Padgett \& Keifert [eds] 2006; Brueggemann 2006). Dit is te begrype dat die verskil in interpretatiewe raamwerke binne Christelike geloofsgemeenskappe dissonansie en daarom spanning en konflik sal veroorsaak (vgl Malherbe \& Louw 2002:512-522). Die rede hiervoor is dat die verskillende paradigmas nie slegs oor verskille met betrekking tot enkele, marginale sake in die Christelike teologie of menslike gedrag handel nie, maar oor verskillende wyses waarop daar oor sogenoemde "kernsake" binne die Christendom gedink word. Om insig te ontwikkel in die aard van die dissonansie by pastors is dit nodig om die twee paradigmas met mekaar te vergelyk.

In die tradisionele paradigma (Borg 2003:9-12; vgl Burton 1988:12-20) neem die Bybel 'n sentrale plek in en word as "God se Woord" beskou. Dit beteken dat God se stem direk in die Bybel gehoor kan word en dat die Bybel daarom 'n bundel met "ewige waarhede" is (kyk Barr 1969; 1973), wat konteksloos na alle tydperke oorgedra kan word, sonder om die historiese gesitueerdheid van die Bybel in ag te neem. Alles in die Bybel is letterlik waar, met ander woorde die gebeure in die Bybel wat as historiese gebeure vertel word, het werklik histories en fisies so gebeur. In hierdie sin is die Bybel "feitelik waar." Indien die historiese gesitueerdheid van die Bybelse inhoud wel in ag geneem word, word geredeneer dat daar sekere "kern waarhede" is wat alle tye transendeer, byvoorbeeld wonderwerke in die Ou Testament soos die Rietsee wat in twee verdeel het, die maagdelike verwekking van Jesus, die wonders van Jesus, die fisiese opstanding van Jesus uit die dood, Jesus se opwekking van Lasarus uit die dood, Jesus se hemelvaart en die bestaan van 'n duiwel.

Die beskouing dat die Bybel "feitelik waar" is, is 'n uitvloeisel van die modernisme wat "waarheid" met "feitelikheid" gelyk stel. Hierdie beskouing van die Bybel hang saam met ' $n$ "meganiese inspirasieleer" wat beteken dat die Bybelskrywers willose instrumente onder beheer van God was en neergeskryf het wat God aan hulle gedikteer het (kyk Roberts 1977:25). Daarom kan daar ook nie "foute" in die Bybel voorkom nie en word Bybelse 
weergawes van gebeure as "onfeilbaar" beskou. So 'n beskouing van die Bybel kan as fundamentalisme ${ }^{2}$ beskryf word.

Die belydenisse en belydenisskrifte speel 'n baie belangrike rol en word as 'n samevatting van die "waarhede" van die Bybel geag. Enige beskouing wat van hierdie "beginsels" afwyk, word as leerdwaling beskou en moet verwerp word omdat dit die gesag van die Bybel en daarom ook die eer van God aantas.

Hieruit vloei voort dat geloof in 'n groot mate gesien word as instemming met leerstellings oor God en die Bybel. Die belydenisskrifte vorm die raamwerk van 'n meesterverhaal wat deur eeue heen vir baie Christene sin en betekenis aan hulle lewe gegee het en vorm ook die "bril" waarmee die Bybel gelees word. Hierdie meesterverhaal kom in kort daarop neer dat een mensepaar, Adam en Eva, vir "die sondeval" van die mensdom verantwoordelik is. Hierdie "feite" word in Genesis 1-3 verhaal en van toe af is die mensdom aan die gevolge van die sondeval en God se oordeel daaroor onderwerp. God as Vader oordeel en straf die sonde deur sy Seun, Jesus Christus, aan 'n kruis te laat sterf en op die derde dag fisies uit die dood op te wek om vir die mensdom se sonde te betaal. Elkeen wat glo dat Jesus Christus God se Seun is en vir haar/sy sonde aan die kruis gesterf het, kry deel aan die uiteindelike beloning, naamlik die "ewige lewe". Diegene wat nie aan hierdie vereistes voldoen nie, is bestem om deur God verdoem en verwerp te word vir ewige lyding in 'n fisiese bestemming, naamlik "die hel". Jesus Christus sal êrens in die toekoms as heerser op die wolke na die aarde terugkeer om oor mense te oordeel.

Ten spyte daarvan dat hierdie paradigma God se gratis liefde en genade vir mense beklemtoon, is daar ' $n$ onderliggende patroon van prestasie

\footnotetext{
${ }^{2}$ Fundamentalisme word deur J N Vorster (1988:155; kyk Barr [1977] 1981; 1980; 1984; Van Huyssteen \& du Toit 1982) omskryf as 'n reaksie vanuit konserwatiewe Christelike kringe op diepgaande veranderings in die kulturele en intellektuele milieu in die VSA in die negentiende eeu. Fundamentalisme kan geplaas word binne die opkoms van empirisme en modernisme wat besondere klem plaas op die objektiewe waarneming van objekte deur middel van die sintuie. Die sogenaamde Scottish common sense realism dien in besonder as filosofiese onderbou vir fundamentalisme (Vorster 1988:160). Hiervolgens is waarheid ' $n$ gefikseerde korpus van gegewens wat in alle omstandighede vir alle mense min of meer dieselfde is en objektief waarneembaar is. Die Bybel is beskou as ' $n$ boek vol feite waaruit met behulp van induktiewe analise tot bepaalde sinteses gekom kan word. Die historiese kritiek het egter die epistemologiese status van die Bybel in gedrang gebring (Vorster 1988:161; kyk Van Huyssteen \& Du Toit 1982; Deist 1986). Fundamentalisme was 'n reaksie hierteen. Fundamentalisme handhaaf die siening dat die Bybel histories korrek is; dat die Bybel geen foute of teensprake bevat nie en daarom goddelik geïnspireerd is; dat die skrywers van die onderskeie Bybelboeke betroubaar was in hulle waarnemings omdat daar ' $n$ direkte verband bestaan tussen die gebeure wat waargeneem is en dit wat in die Bybel opgeteken staan. Deur middel van grammaties-historiese eksegese word woorde en frases op atomistiese wyse buite konteks geanaliseer, wat aan die eksegeet toegang gee tot die historiese omstandighede waarin dit geskryf is. Sodoende kan die eksegeet "die waarheid" bekom en beheer.
} 
en beloning in die logika daarvan waarneembaar. Die beloning waarna elke mens behoort te streef is die "ewige lewe". Om hierdie beloning te ontvang moet mense hulleself aan 'n bepaalde geloof, asook 'n toegewyde lewe verbind. Hierdie paradigma is eksklusiwisties in die sin dat nie alle mense die geseënde "lewe na die dood" van God sal ontvang nie, maar slegs diegene wat erken en bely dat Jesus Christus "die weg en die waarheid en die lewe" (Joh 14:6) is. Borg (2003:11) verwoord die voorwaardelikheid van hierdie beskouing oor genade soos volg: "Of course, the earlier paradigm uses the language of God's grace and compassion and love, but its own internal logic turns being Christian into a life of requirements and rewards, thereby compromising the notion of grace. Indeed, it nullifies grace, for grace that has conditions attached, is no longer grace."

Die opkomende paradigma word opsommend deur Borg (2003:13-14) onder twee temas beskryf, naamlik "a way of seeing the Bible (and the Christian tradition as a whole): historical, metaphorical, and sacramental" en "a way of seeing the Christian life: relational and transformational." Die opsomming wat hieronder volg word gedoen aan die hand van bogenoemde vyf adjektiewe wat Borg as raamwerk vir sy omskrywing aanwend, naamlik "historical, metaphorical, sacramental, relational, transformational." Die Bybel word gesien as die produk van 'n lang historiese proses en reflekteer onder andere antieke mense se geloof oor God, hulle godsdiens- en wêreldbeskouing, die wyse waarop die gemeenskap ingerig en georden moet word, asook verhoudings tussen mense, dinge en plekke. Die Bybel is nie vir mense van die een-en-twintigste eeu geskryf nie, maar wel vir die mense in die tyd waarin dit ontstaan het. Daar bestaan 'n historiese afstand van ten minste twee millennia tussen vandag se Bybellesers en die mense van oud-Israel en die eerste Christene. Bewussyn van hierdie historiese afstand is belangrik wanneer die Bybel gelees en geïnterpreteer word.

"The emerging paradigm sees the Bible metaphorically, by which I mean its 'more-than-literal,' 'more-than-factual,' meaning” (Borg 2003:13; my beklemtoning). Hierdie uitspraak van Borg beklemtoon die beskouing dat die Bybelse verhale waar kan wees, sonder om histories "korrek" te wees. Vir die opkomende paradigma is die betekenis van die Bybel vir mense nie in letterlike, historiese gebeure geleë nie, maar in die betekenis wat Bybelse verhale vir mense se lewens het. Daarom is dit byvoorbeeld nie belangrik dat Jona letterlik, fisies vir drie dae in ' $n$ vis se maag moes oorleef sodat die verhaal betekenis kan hê nie en kan 'n verhaal soos dié van Ester as 'n novelle gelees word en steeds waarde hê vir mense van vandag. Hierdie paradigma vra nie presies hoe en wanneer en waar dinge in die Bybelse 


\section{Pastors as gewonde genesers}

verhale gebeur het nie, maar vra eerder na die betekenis van die verhale vir postmoderne mense. Die evangelies se weergawes oor Jesus se geboorte en opwekking word metafories verstaan en nie as feitelike verslae nie. Die Bybel word as mense se woorde oor God beskou en nie as "God se Woord(e)" nie.

'n Sakramentele ${ }^{3}$ beskouing van die Bybel word soos volg deur Borg (2003:14) geformuleer: “... I mean the Bible's ability to mediate the sacred. A sacrament is something visible and physical whereby the Spirit becomes present to us. A sacrament is a means of grace, a vehicle or vessel for the Spirit." Hoewel die Bybel nie as "Woord van God" beskou word nie, kan mense deur die lees van die Bybel ervaar dat God in hulle lewens teenwoordig is en deur Bybelse verhale met hulle kommunikeer.

Die Bybel word as heilige geskrifte beskou in terme van die funksie en status daarvan, maar nie in terme van die ontstaan daarvan nie (kyk Barr [1977] 1981; 1980; 1984). Die modernistiese, tradisionele paradigma het tot gevolg dat mense in die Bybel en in Christelike leerstellinge (ook oor die Bybel) glo (Van Aarde 1999:437-470; 2004:503-532). Die opkomende paradigma wil daarteenoor 'n verhouding met God (relasionele funksie van die Bybel) voed, met die Christelike tradisie (wat die Bybel insluit) as voedingsbron, "as a metaphor and sacrament of the sacred" (Borg 2003:14).

Die Christelike lewe word as 'n proses van verhoudings en transformasie beskou. Die betekenis van Christenwees is nie in die nakoming van voorwaardes ter wille van 'n ewige lewe (of 'n geseënde/suksesvolle lewe hier en nou) geleë nie, maar wel in 'n verhouding met God waaruit transformasie van mense se lewens na vore tree. Hierdie transformasie omvat alle verhoudings waarin mense staan, naamlik hulle verhouding met God, met hulleself, met ander en met hulle omgewing.

Religieuse pluraliteit word in die postmoderne paradigma erken en ernstig geneem. Die Christelike geloof word as een van die wêreld se groot godsdienste beskou, maar nie as die enigste wyse waarop mense God outentiek kan ervaar nie. Ook wat hierdie aspek betref, word die historiese en kulturele gesitueerheid met betrekking tot die godsdiens wat mense as hulle eie aanneem, erken. Die eiesoortigheid van die Christelike geloof word egter in hierdie paradigma ernstig opgeneem en eksponente daarvan is oortuig van die betekenis daarvan vir mense se verhouding met God, met hulleself en met die samelewing.

Temas wat vir die tradisionele paradigma belangrik is (geloof, die Bybel, God, Jesus, wedergeboorte, die koninkryk van God, sonde en verlossing, 'n Christelike lewenswyse), word ook in die opkomende paradigma

\footnotetext{
${ }^{3}$ Die term "sakrament" word nie deur Borg gebruik as verwysing na óf die vroeëre Latynse betekenis van sacramentum as 'n militêre begrip vir 'n "pledge of fidelity" nie (kyk Thatcher 1999:40) óf in dogmatiese sin as een van sewe of twee "sakramente" nie (sedert o a Thomas Aquinas, Summa theologiae II-IIIQ.154; kyk Schillebeeckx 1965).
} 
ernstig geneem, maar word met ander inhoud gevul (kyk Borg 2003:25-226). Omdat die twee paradigmas so uiteenlopend van aard is en verskil ten opsigte van temas wat in belydenisse verwoord is, is versoening tussen die twee paradigmas moeilik (indien enigsins) haalbaar.

\section{GENESING AS TRANSFORMASIE}

\section{1 'n Paradigmaskuif}

Vir hierdie studie is die postmoderne dekonstruksie van mag ook van belang, omdat daarmee saam die tradisionele ampsbeskouing van kerke met die mag wat aan die amp van predikant geheg was, ook in gedrang kom. Daar word insig en wysheid van pastors vereis om in die eerste plek klaarheid te kry oor watter paradigma hulleself aanvaar en in die tweede plek op watter wyse die verskille tussen die twee paradigmas in hulle geloofsgemeenskappe gefasiliteer moet word. Pastors wat vanuit die opkomende paradigma dink en funksioneer, kan onder spanning verkeer wanneer daar oor temas soos Skrifgesag, die funksie van kerklike belydenisse, die maagdelike verwekking van Jesus en sy opwekking uit die dood, asook oor sake soos homoseksualiteit, die toelating van vroue tot die kerklike ampte en die vraag oor watter godsdiens "die ware godsdiens" is, gereflekteer word. Malherbe \& Louw (2002:519; vgl Burton 1988:46-60), is van mening dat 'n paradigma van onderhandeling ("negotiation") die moontlikheid bied om die verskillende paradigmas te kombineer sodat bediening in 'n pluralistiese samelewing meer effektief kan wees. Of dit wel haalbaar is, bly 'n ope vraag aangesien paradigmas moeilik met mekaar versoenbaar is (kyk Kuhn [1962] 1970:160173).

'n Nuwe paradigma is nie die somtotaal van verskeie elemente uit vorige en nuwe paradigmas nie, maar 'n radikale breuk met interpreterende raamwerke van vroeër. Wanneer 'n navorsingsgemeenskap 'n vorige paradigma verwerp, verwerp dit ook die meeste van die wetenskaplike werke (handboeke en artikels) wat daardie paradigma beliggaam het (Kuhn 1970:167). Daar kan gevra word wie bepaal watter elemente uit verskillende paradigmas geldig genoeg is om saam gegroepeer te word, asook watter temas uit 'n premoderne paradigma ondergeskik aan die moderne en postmoderne paradigmas sou wees en om watter redes. Paradigmas is nie "objektiewe" verwysingsraamwerke nie, maar word deur bepaalde individue en groepe se interesse bepaal. Burton (1988:46-60) beklemtoon dat onderhandeling tussen mense in 'n postmoderne paradigma belangrik is sodat verskillende groepe, veral voorheen gemarginaliseerde groepe, se stemme gehoor kan word. 


\section{Pastors as gewonde genesers}

'n Postmoderne paradigma beteken egter nie dat enige standpunt geldig is nie, wat onder andere beteken dat 'n fundamentalistiese lees van die Bybel nie as geldig aanvaar kan word nie. Dit is veral ten opsigte van hierdie laaste saak dat spanning tans in die Suid-Afrikaanse teologiese en kerklike konteks en veral by pastors ervaar word soos die afgelope aantal jare uit kerklike diskoerse en besluite blyk oor sake soos die maagdelike verwekking van Jesus, die interpretasie van die opstandingsberigte in die evangelies, asook die vraag oor die seksualiteit van gays en gay-huwelike. Binne die kerklike gemeenskap waarvan ek deel is is daar tans met die aanloop tot die eersvolgende Algemene Kerkvergadering debatte aan die gang oor die sogenaamde volkskerkidee, die vraag of apartheid as sonde bely moet word of nie en die ekumeniese betrokkenheid van die Hervormde Kerk al dan nie. Die verskille wat in hierdie debatte na vore kom kan na verskille in Skrifbeskouing teruggevoer word, wat op 'n dieper vlak met mense se geloof in God in verband staan, omdat daar geworstel word met die vraag oor hoe die Bybel vandag as "God se Woord" verstaan kan word en of Bybelse getuienisse enigsins as geldig vir die hedendaagse samelewing geag kan word. Die onsekerheid wat deur diskoerse soos hierdie veroorsaak word, tesame met die trauma met betrekking tot die politieke en sosiale transformasie in Suid-Afrika vanaf 1990, verdiep die emosionele spanning en kognitiewe dissonansie waarmee pastors leef.

\subsection{Geneesde genesers}

Onsekerheid en relatiwiteit lei nie noodwendig tot relativisme nie. Pastors hoef nie in wanhoop te verval omdat die kultuur waarbinne hulle leef "objektiewe waarhede" van die verlede bevraagteken nie. Dit is egter belangrik dat pastors die verskynsel van postmoderniteit en die verwonding en verlamming wat hulle as gevolg daarvan beleef, sal verstaan. Wanneer pastors insig en begrip oor hierdie sake ontwikkel, kan dit tot heling ("healing"/“wholeness") in hulle eie lewens lei en hulle bemagtig om hulle bediening op 'n sinvolle wyse uit te voer. Op hierdie wyse kan hulle op grond van insig in hulleself as gewonde genesers ("wounded healers") tot geneesde genesers ("healed healers") in relasie met ander tree en hulle begelei tot genesing.

Die term "genesing" word hier nie in kliniese mediese sin verstaan nie, maar in kultuur-antropologiese sin. Stuart Bate (1995) gebruik die term "coping-healing" na aanleiding van die navorsing van onder andere G Easthope (1986) en A Kleinman (1978, 1980). Die "proses" om van verwondheid na genesing te kom, kom nie tot voltooiing asof 'n "healed healer" in "volmaaktheid" gearriveer het nie. Easthope (1986:116-124) beskryf die "genesende proses" as 'n "transformasie van identiteit" - 'n transformasie 
wat die gevolg is van 'n verandering in sosialisering. Bate (1995:114) verwoord sy eie beskouing hieroor soos volg: "The healing process involves the reconstruction of a person's identity in terms of the more positive symbols of the new social or religious grouping in which that person is healed. A new process of socialisation into 'this world' occurs and this is experienced as healing."

Om 'n "geneesde geneser" te wees beteken dat mense insig in hulle eie verwondheid ontwikkel en daarom ander mense vanuit hulle eie situasie van verwonding kan begelei. "Genesing" impliseer nie dat net "skoon, rein" mense iets vir ander kan beteken nie (genesing teenoor siek/gebroke, skoon/rein teenoor vuil): iemand moet dus eers genees word (en wie bepaal in elk geval wanneer is iemand "genees"?) en dan kan so iemand anders "genees". lemand kan ook nie iemand anders "genees" nie, maar kan net van sy/haar eie verwondheid bewus word en vanuit daardie disposisie, met versigtigheid en verantwoordelikheid en deernis met mense omgaan. Die vertellings oor die vroeë Christene in die Handelinge van die Apostels toon dat die apostels "healed healers" was, nie in die sin dat hulle "genees" was nie, maar eerder in die sin dat hulle met wonde en al op "die weg van Jesus" gegaan het. William Neil (1973:56) stel dit soos volg in sy eksegetiese kommentaar op die Handelinge van die Apostels:

For the restoration of wholeness to mind and body in the case of the diseased and the mentally disturbed was done in the name of Jesus by men who had been endowed with his Spirit to continue his work. Some of the acts of healing which Luke records were performed by the same men who had earlier been given authority by Christ himself in Galilee to preach the Gospel and to heal the sick. What they and other missionaries were now doing in a wider field was part of the same ministry; they were channels of the healing power of Christ...

Pastors kan op verskillende wyses met die spanning van emosionele verlamming omgaan. ' $n$ Weg wat in hierdie studie bedink word vir pastors wat op 'n verantwoordelike wyse daarmee wil omgaan, is die weg van bewuswording en integrasie. Hiermee word in die eerste plek bedoel pastors se bewuswording van die twee verskillende paradigmas, bewuswording van watter paradigma hulle aanvaar en die bewustelike integrering daarvan op kognitiewe sowel as emosionele vlak. In die tweede plek word bedoel dat pastors bewus raak van die impak wat die eerste proses op hulle emosionele funksionering het en die sinvolle hantering van daardie emosies. 
Emosionele intelligensie ${ }^{4}$ is ' $n$ belangrike deel van hierdie proses.

Emosionele intelligensie kan kernagtig beskryf word as mense se vermoë om van hulle eie emosies, asook die emosies van ander persone, bewus te raak en dit sinvol en verantwoordelik te integreer en bestuur (kyk Mayer \& Salovey 1997:3-31; Mayer, Caruso \& Salovey 1999:267-298; Mayer, Salovey \& Caruso 2000a:396-420; Mayer, Salovey \& Caruso 2000b:92-116; Mayer 2001:3-24). Emosionele intelligensie is nie ekwivalent aan positiewe denke nie. Dit beteken dat negatiewe emosies nie ontken hoef te word nie. Dit is deel van 'n proses van persoonlike transformasie, of individuasie soos Carl Jung ([1911-1912] 1952; [1940] 1950; [1959] 1978) dit formuleer, waardeur mense as unieke individue ontwikkel. Wanneer pastors in hulle kennismaking met ' $n$ nuwe paradigma van negatiewe emosies bewus raak, beteken emosionele intelligensie dat hulle die oorsaak van sodanige emosies sal probeer vasstel. In die proses kan hulle ontdek dat negatiewe emosies wat aanvanklik deur hulleself as "spanning" of "ongemak" beskryf is, tot dieperliggende emosies, soos "angs" of "vrees", herlei kan word. Hierdie emosies spruit uit vooroordeel teenoor 'n nuwe paradigma en selfs teenoor sekere persone wat binne 'n nuwe paradigma funksioneer.

Daar kan nie skeiding tussen die eerste en die tweede prosesse soos hierbo beskryf is (bewuswording en emosionele effek) gemaak word nie, aangesien kognitiewe en emosionele bewuswording van bepaalde prosesse en gebeure gelyktydig plaasvind en in interaksie met mekaar verkeer. Kognitiewe refleksie het emosionele prosesse tot gevolg, terwyl emosionele belewenisse denkprosesse beïnvloed. Die waarde van hierdie bewuswordingsprosesse is dat emosionele genesing by pastors kan plaasvind, wat 'n positiewe effek op hulle totale funksionering uitoefen.

\section{Literatuurverwysings}

Barr, J 1969. The authority of the Bible. Ecumenical Review 21(92), 135-166.

Barr, J 1973. The Bible in the modern world. London: SCM.

Barr, J [1977] 1981. Fundamentalism. London: SCM.

Barr, J 1980. The scope and authority of the Bible. London: SCM.

Barr, J 1984. Beyond fundamentalism. Philadelphia, PA: Westminster.

Bate, S C 1995. Inculturation and healing: Coping-healing in South African

Christianity. Pietermaritzburg: Cluster.

Boisen, A T [1936] 2005. The living human document, in Dykstra, R C (ed), Images of pastoral care: Classic readings, 22-29. St Louis, MO: Chalice.

Borg, M J 2003. The heart of Christianity: Rediscovering a life of faith. San Fransisco, CA: HarperSanFransisco.

\footnotetext{
${ }^{4}$ Vir 'n uiteensetting van wat onder die begrip emosionele intelligensie verstaan word, en die waarde daarvan vir pastors se menswees en bediening, kyk Nolte (2008).
} 
Brueggemann, W 2006. The Bible makes sense. Rev edition. Cincinatti, OH: St Anthony Messenger.

Burton, L A 1988. Pastoral paradigms: Christian ministry in a pluralistic culture. Washington DC: Alban Institute.

Deist, F 1986. Kan ons die Bybel dan nog glo? Onderweg na 'n Gereformeerde Skrifbeskouing. Pretoria: Van Schaik.

Dykstra, R C 2005a. Introduction, in Dykstra, R C (ed), Images of pastoral care: Classic readings, 1-14. St Louis, MO: Chalice.

Easthope, G 1986. Healers and alternative medicine: A sociological examination. Shaftesbury: Blackmore.

Frank, A W 1995. The wounded storyteller: Body, illness, and ethics. Chicago, IL: The University of Chicago Press.

Heitink, G [1977] 1984. Pastoraat als hulpverlening: Inleiding in de pastorale theologie en psychologie. Kampen: Kok.

Hodgson, O C 1994. Winds of the Spirit: A constructive Christian theology. London: SCM.

Holliday, M A K 1978. Language as a social semiotic: The social interpretation of language and meaning. Baltimore, MD: Baltimore University Press.

Jung, C G [1911-1912] 1952. Symbols of transformation: An anlaysis of the prelude to a case of schizophrenia: Collected Works of C G Jung 5, in Read, $\mathrm{H}$, Fordham, M, Adler, G \& McGuire, W (eds), tr by R F C Hull. Princeton, NJ: Princeton University Press.

Jung, C G [1940] 1950. The integration of the personality, tr by S Dell. London: Routledge \& Kegan Paul.

Jung, C G [1959] 1978. AION. Researches into the phenomenology of the self, Collected Works of C G Jung 9/2, in Read, H, Fordham, M, Adler, G \& McGuire, W (eds), tr by R F C Hull. London: Routledge \& Kegan Paul.

Kleinman, A, Eisenberg, L \& Good, B 1978. Culture, illness, and care: Clinical lessons from anthropological and cross-cultural research. Annals of Internal Medicine 88, 251-258.

Kleinman, A 1980. Patients and healers in the context of culture. Berkeley, CA: University of California Press.

Kuhn T S [1962] 1970a. The structure of scientific revolutions. Chicago, IL: University of Chicago.

Malherbe, P B \& Louw, D J 2002. Die dinamika tussen teologiese paradigmas en die verskynsel van uitbranding in die bediening. NGTT 43(3\&4), 513-522.

Malina, B J 2001. The New Testament world: Insights from cultural anthropology. Revised and expanded edition. Louisville, KY: Westminster John Knox.

Mayer, J D \& Salovey, P 1997. What is emotional intelligence?, in Salovey, P \& Sluyter, D (eds), Emotional development and emotional intelligence: Implications for educators, 3-31. New York: Basic Books.

Mayer, J D, Caruso, D \& Salovey P 1999. Emotional intelligence meets traditional standards for intelligence. Intelligence 27, 267-298.

Mayer, J D, Salovey, P \& Caruso, D 2000a. Models of emotional intelligence, in Handbook of intelligence, 396-420. Cambridge, UK: Cambridge University Press. 
Mayer, J D, Salovey, P \& Caruso, D 2000b. Emotional intelligence as Zeitgeist, as personality, and as mental ability, in Bar-On, R \& Parker, J D A (eds), Handbook of emotional intelligence: Theory, development, assessment, and application at home, school, and in the workplace, 92-116. San Fransisco, CA: Jossey-Bass.

Mayer, J D 2001. A field guide to emotional intelligence, in Ciarrochi, J, Forgas, J P \& Mayer J D (eds), Emotional intelligence in everyday life: A scientific enquiry, 3-24. Lillington, NC: Edwards Brothers.

Miller-McLemore, B J 1996. The living human web: Pastoral theology at the turn of the century, in Stevenson Moessner, J (ed), Through the eyes of women: Insights for pastoral care, 9-26. Minneapolis, MN: Fortress.

Neil, W 1973. The acts of the apostles. Londen: Oliphants. (New Century Bible.)

Nolte, S P 2008. Pastors as gewonde genesers: PhD-proefskrif, Universiteit van Pretoria.

Padgett, A G \& Keifert, P R (eds) 2006. But is it all true?: The Bible and the question of truth. Grand Rapids, MI: William B Eerdmans.

Roberts, J H 1977. Inleiding tot die studie van die Nuwe Testament: Prinsipiële gesigspunte en terreinverkenning, in Roberts, J H \& Du Toit, A B (reds), Handleiding by die Nuwe Testament, Band 1, 1-80. Pretoria: NG Kerkboekhandel.

Schillebeeckx, E 1965. Marriage: Human reality and saving mystery. London: Sheed \& Ward.

Thatcher, A 1999. Marriage after modernity: Christian marriage in postmodern times. Sheffield: Sheffield Academic Press.

Tracy, D 1994. Theology and the many faces of postmodernity. Theology Today 51(1), 104-114.

Van Aarde, A G 1999. Dekonstruksie van dogma: 'n Eietydse ondersoek na die spore van die leer van die twee nature van Jesus. HTS 55(2\&3), 437-470.

Van Aarde, A 2004. Skrifbeskouing in die lig van postmoderniteit. HTS 60(1\&2), 503532.

Van Huyssteen, J W \& Du Toit, B 1982. Geloof en Skrifgesag: 'n Analise van die Skrifgesagprobleem na aanleiding van die rapport "God met ons". Pretoria: NG Kerkboekhandel.

Vorster, J N 1988. The use of Scripture in fundamentalism, in Mouton, J, Van Aarde, A G \& Vorster, W S (eds), Paradigms and progress in theology, 155-175. Pretoria: HSRC. (HSRC Studies in Research Methodology 5.)

Webster, J 2003. Holy Scripture: A dogmatic sketch. Cambridge: Cambridge University Press. 